\title{
Knowledge and practice of pediatricians and nutritionists regarding treatment of cow's milk protein allergy in infants
}

\section{Conhecimento e prática de pediatras e nutricionistas sobre o tratamento da alergia às proteinas do leite de vaca em lactentes}

\author{
Dayane Pêdra Batista de FARIA ${ }^{1}$ (D) 0000-0003-4895-6397 \\ Ana Paula Bidutte CORTEZ1 (iD) 0000-0001-6574-6506 \\ Patrícia da Graça Leite SPERIDIÃO² (iD 0000-0002-5276-9001 \\ Mauro Batista de MORAIS ${ }^{3}$ (D) 0000-0003-4014-5549
}

\section{A B S T R A C T}

\section{Objective}

This study evaluated the knowledge and practices of pediatricians and nutritionists about cow's milk protein allergy in infants, with an emphasis on issues related to the exclusion diet and nutritional status.

\section{Methods}

A cross-sectional, descriptive study was performed with a convenience sample of 204 pediatricians and 202 nutritionists randomly invited in scientific events in the city of São Paulo, from November 2014 to March 2016.

\footnotetext{
1 Universidade Federal de São Paulo, Escola Paulista de Medicina, Programa de Pós-Graduação em Nutrição. R. Marselhesa, 630, Vila Clementino, 04020-060, São Paulo, SP, Brasil. Correspondência para/Correspondence to: DPB FARIA. E-mail: <dayanefaria19@hotmail.com>.

2 Universidade Federal de São Paulo, Instituto de Saúde e Sociedade, Programa de Pós-Graduação em Alimentos, Nutrição e Saúde. Campus Baixada Santista, Santos, SP, Brasil.

3 Universidade Federal de São Paulo, Escola Paulista de Medicina, Departamento de Pediatria. São Paulo, SP, Brasil.

Support: Conselho Nacional de Desenvolvimento Científico e Tecnológico (CNPq) (Processo no 133534/2015-4).

Article based on the dissertation by DPB FARIA entitled "Conhecimento de pediatras e nutricionistas sobre o tratamento da alergia às proteinas do leite de vaca em lactentes”. Universidade Federal de São Paulo; 2017.
}

Como citar este artigo/How to cite this article

Faria DPB, Cortez APB, Speridião PGL, Morais MB. Knowledge and practice of pediatricians and nutritionists regarding treatment of cow's milk protein allergy in infants. Rev Nutr. 2018;31(6):535-46. http://dx.doi.org/10.1590/1678-98652018000600003 


\section{Results}

Between $1.5 \%$ and $21.0 \%$ of respondents indicated inadequate products for the treatment of cow's milk protein allergy, including goat's milk, beverages or juices based on soy extract, lactose-free milk formula and partially hydrolyzed formula. The daily calcium recommendation for children between zero and 36 months of age was correctly indicated by $27.0 \%$ of pediatricians and $46.0 \%$ of nutritionists $(p=0.001)$. Additionally, $96.1 \%$ of pediatricians and $82.7 \%$ of dietitians $(p<0.001)$ provided guidance on about labels of industrialized products.

\section{Conclusion}

Pediatricians and nutritionists present gaps in knowledge about cow's milk protein allergy treatment in infants and educational strategies that increase the knowledge of the professionals are important for the management of cow's milk protein allergy.

Keywords: Cow's milk allergy. Infant. Knowledge attitude and practice. Pediatricians. Nutritionists.

\section{RE S U M O}

\section{Objetivo}

Este estudo avaliou o conhecimento e práticas de pediatras e nutricionistas sobre alergia às proteínas do leite de vaca em lactentes, com ênfase em questões relacionadas à dieta de exclusão e ao estado nutricional.

\section{Métodos}

Estudo transversal, descritivo, realizado com uma amostra de conveniência de 204 pediatras e 202 nutricionistas, convidados aleatoriamente em eventos científicos na cidade de São Paulo, de novembro de 2014 a março de 2016.

\section{Resultados}

Entre 1,5\% e 21,0\% dos entrevistados indicaram produtos inadequados para o tratamento da alergia às proteínas do leite de vaca, incluindo leite de cabra, bebidas ou sucos à base de extrato de soja, fórmula de leite sem lactose e fórmula parcialmente hidrolisada. A recomendação diária de cálcio para crianças entre zero e 36 meses de idade foi corretamente indicada por 27,0\% de pediatras e 46,0\% de nutricionistas $(p=0,001)$. Além disso, $96,1 \%$ dos pediatras e $82,7 \%$ dos nutricionistas $(p<0,001)$ forneceram orientação sobre os rótulos dos produtos industrializados.

\section{Conclusão}

Pediatras e nutricionistas apresentam lacunas no conhecimento sobre o tratamento da alergia às proteínas do leite de vaca em lactentes. Estratégias educacionais que aumentam o conhecimento dos profissionais são importantes para o gerenciamento da alergia às proteínas do leite de vaca.

Palavras-chave: Alergia ao leite de vaca. Crianças. Conhecimento, atitudes e prática. Nutricionistas. Pediatras.

\section{NTROD U CTION}

Food allergy is an adverse health effect arising from a specific immune response that occurs reproducibly following exposure to a given food [1]. The main cause of food allergies in children under three years old is Cow's Milk Protein (CMP) [2].

The estimated prevalence of Cow's Milk Protein Allergy (CMPA) is $2 \%$ to $3 \%$ in the first year of life [2]. In Brazil an observational study conducted in pediatricians' offices revealed a gastroenterologist-diagnosed prevalence of $5 \%$ in the group of patients [3].

The immune mechanisms involved in CMPA may be immunoglobulin (Ig)E mediated (with production of IgE-specific antibodies), which presents immediate symptoms such as urticaria and angioedema, or the non lgEmediated (T-cell mediated), which manifests through later reactions, such as vomiting, diarrhea, colic and intestinal constipation. Mixed reactions (immediate and late) can also occur, such as eosinophilic esophagitis, eosinophilic 
gastroenteropathy, atopic dermatitis and asthma [1,4-6].

The diagnosis and treatment of CMPA is based on the exclusion of CMP from the diet. Cow's milk elimination without adequate replacement may impair the normal growth and development of the child [1,4-7].

During the period of exclusion of CMP, a nutritional status assessment should be performed by the health professional to establish the adequacy of food consumption for the child's nutritional needs $[1,4,5,8]$ and family members must be oriented to perform a thorough reading of the labels of industrialized foods offered to their children $[1,5,7,9]$. Despite the existence of several guidelines [1,4-7,10-13] for the diagnosis and treatment of CMPA, some surveys $[6,7,14-22]$ have shown that the practices and knowledge of health professionals are not fully in line with these recommendations. Few studies have investigated the knowledge and practices of pediatricians and nutritionists about CMPA treatment. Studies $[15,16,19]$ conducted in Brazil have shown gaps in knowledge and have confirmed that not all behaviors are consistent with the recommendations.

Thus, this study aimed to evaluate the knowledge and practice of pediatricians and dietitians about CMPA in infants, with an emphasis on issues related to the exclusion diet and nutritional status.

\section{METHODS}

\section{Study design}

This study had a cross-sectional descriptive design involving a convenience sample of 406 professionals. Data collection was conducted from November 2014 to March 2016.

The invitation to professionals to participate in the study was issued randomly at five scientific events held in the city of São Paulo: $10^{\text {th }}$ Update Course on Pediatrics, Nutrition Mega
Event, $9^{\text {th }}$ Conference on Pediatric Nutrition, $6^{\text {th }}$ Brazilian Conference on Integrated Nutrition (Ganepão) and 14 ${ }^{\text {th }}$ São Paulo State Conference on Pediatrics.

The study was approved by the Ethics Committee in Research of the Universidade Federal de São Paulo (UNIFESP, Federal University of São Paulo) under No.842.114. Free and informed consent was obtained in writing from all participants.

\section{Structured form}

Data collection was performed through a structured and self-administered form that was previously described by Cortez et al. [15]. This form was reevaluated and adapted based on updates for the treatment of CMPA. The form was composed of an initial section to characterize the professional (i.e., gender, time since college graduation, graduate course and location of professional action). The second section consisted of questions about knowledge of and practices for the treatment of infants with CMPA.

The following statements were presented to enable the interviewees to express agreement, disagreement or lack of knowledge and multiple choice questions.

\section{Knowledge about breastfeeding and bottle feeding}

1) Casein is the only milk protein involved in triggering CMPA; 2) The early introduction of cow's milk increases the risk of CMPA development; 3) Exclusively breastfed infants can develop CMPA; 4) A child with CMPA may present a cross reaction to soybean proteins; 5) Goat's milk or milk from any other mammal (e.g., sheep, mare, or donkey) can be used as a substitute for cow's milk for children with CMPA; 6) Patients with lactose intolerance should exclude all foods containing CMP from the diet. 
One question evaluated whether the interviewees knew the products that could be used to replace CMP in the diets of infants over six months of age with suspected nonIgE-mediated or IgE-mediated CMPA. The alternatives were presented with the definition of the type of formula (with the respective brand name) as follows: (1) extensively hydrolyzed formula; (2) soy protein-based formula; (3) Goat's milk; (4) soy extract-based beverage/ juice; (5) lactose-free milk formula; (6) amino acid-based formula; and (7) partially hydrolyzed formula. More than one option could be chosen for these questions. Some care practice scenarios were also presented.

We asked what the initial prescription for special formula would be for an infant less than six months of age (using infant formula) with suspected gastroesophageal reflux disease secondary to CMPA associated with a weight deficit. The following alternatives (with their brand names) were presented: (1) extensively hydrolyzed formula; (2) soy protein-based formula; (3) Goat's milk; (4) soy extract-based beverage/juice; (5) lactose-free milk formula; (6) amino acid-based formula; and (7) partially hydrolyzed formula.

\section{Other food allergens}

For children with CMPA, other allergenic foods, such as soy, eggs, fish and peanuts, should also be eliminated from the diet as a preventive measure to avoid other reactions.

\section{Daily calcium requirements (clinical scenario)}

A question was based on a clinical scenario involving a 15-month-old patient fed $450 \mathrm{~mL}$ of extensively hydrolyzed formula with complementary feeding and whether this patient would require calcium supplementation. Three alternatives were offered as a response (yes, no and I do not know). Another issue addressed the recommendation for the daily calcium intake according to age group. The following question was asked: what total dose of calcium do you recommend as a daily intake (mg/day) for the following age groups? The response options were as follows: 0-6 months: 200, 260 or 400; 7-12 months: 260,400 or $600 ; 13-36$ months: 400 , 700 or 900 ; another dose; and I do not know. Another question explored the need for calcium supplementation (considering the consumption of different substitution formulas) for patients with a CMPA. The following alternatives were presented: (1) for patients aged 0-6 months; (2) for patients aged 7-12 months; (3) for patients aged 13-36 months; and (4) other.

\section{Reading of labels and identification of terms related to cow's milk and dairy products in industrialized products}

The answers were based on yes and no alternatives. If the answerwasyes, the interviewee chose which of the following ingredients should be recognized by the parents/guardians and excluded from the diet: maltodextrin; calcium; lactalbumin; casein; caseinate; hydrogenated vegetable fat; milk compound; calcium stearoyl lactyl lactate; lactic acid; serum proteins; lactic yeast; cocoa butter; and hydrolyzed or partially hydrolyzed milk protein.

\section{Statistical Methods}

Statistical calculations were performed using the Epi-Info software version 3.4.3 (Atlanta, Georgia, United States) by setting the level for rejection of the null hypothesis at $5 \%$. The Chi-square test was used for the comparison of proportions. When necessary, the exact Fisher test was used.

\section{RE S U L T S}

A total of 406 professionals were interviewed (204 pediatricians and 202 
nutritionists). Regarding gender, women predominated, corresponding to $88.7 \%$ (360/406) of the sample. The percentage of female respondents was higher $(p<0.001)$ among the nutritionists $(97.0 \% ; 196 / 202)$ than in the pediatric group $(80.4 \% ; 164 / 204)$.

All of the pediatricians worked in a clinic, outpatient clinic, basic health unit, inpatient/ intensive care unit, pediatric emergency and/ or family health program. Of the nutritionists, $23 / 202(11.4 \%)$ did not work in nutritional assistance services for patients.

Table 1 presents the results related to the knowledge and practices of the interviewees about CMPA and its treatment. Generally, the frequency of correct answers was greater among the pediatricians. The nutritionists had less knowledge about the ineffectiveness of milk from other mammals as a substitute for cow's milk and the exclusion of other allergenic foods to prevent other reactions. Notably, the highest frequency of incorrect responses for both the pediatricians and dietitians was found for the possibility of a cross-reaction between CMP and soy proteins.

Figure 1 shows the products considered suitable by pediatricians and dietitians to replace CMP for infants with non-lgE-mediated CMPA (0-24 months) or IgE-mediated CMPA (older than six months). The infant formulas most frequently advocated were extensively hydrolyzed and amino acids. One result that should be highlighted is the use of soy protein-

Table 1. Number and percentage of correct answers provided by pediatricians and nutritionists for the following statements about cow's milk protein allergy. São Paulo (SP), Brazil, 2016.

\begin{tabular}{|c|c|c|c|c|c|c|}
\hline \multirow{3}{*}{ Statements } & \multirow{3}{*}{$\begin{array}{l}\text { Correct } \\
\text { answer }\end{array}$} & \multicolumn{4}{|c|}{ Number (\%) of hits } & \multirow{3}{*}{$p^{1}$} \\
\hline & & \multicolumn{2}{|c|}{$\begin{array}{l}\text { Pediatricians } \\
\qquad(n=204)\end{array}$} & \multicolumn{2}{|c|}{$\begin{array}{l}\text { Nutritionists } \\
\qquad(\mathrm{n}=202)\end{array}$} & \\
\hline & & $n$ & $\%$ & $\mathrm{n}$ & $\%$ & \\
\hline $\begin{array}{l}\text { Early introduction of cow's milk increases the risk of } \\
\text { developing a cow's milk protein allergy }\end{array}$ & Agree & 193 & 94.6 & 181 & 89.6 & 0.091 \\
\hline $\begin{array}{l}\text { Casein is the only milk protein that is involved in the } \\
\text { triggering of a cow's milk protein allergy }\end{array}$ & Disagree & 187 & 91.6 & 149 & 73.7 & $<0.001$ \\
\hline $\begin{array}{l}\text { Exclusively breastfed infants can develop cow's milk } \\
\text { protein allergy }\end{array}$ & Agree & 183 & 89.7 & 130 & 64.4 & $<0.001$ \\
\hline $\begin{array}{l}\text { A child allergic to cow's milk protein may cross-react with } \\
\text { soy proteins }\end{array}$ & Disagree & 6 & 2.9 & 30 & 14.8 & $<0.001$ \\
\hline $\begin{array}{l}\text { Goat's milk or any other animal milk (i.e., sheep, mare, } \\
\text { or donkey) can be used as a cow's milk substitute for } \\
\text { children with a cow's milk protein allergy }\end{array}$ & Disagree & 180 & 88.2 & 112 & 55.4 & $<0.001$ \\
\hline $\begin{array}{l}\text { Patients with lactose intolerance should exclude all foods } \\
\text { containing cow's milk protein from their diet }\end{array}$ & Disagree & 170 & 83.3 & 148 & 73.3 & 0.192 \\
\hline $\begin{array}{l}\text { For children with cow's milk allergy, other allergenic } \\
\text { foods, such as soy, eggs, fish, and peanuts, should also } \\
\text { be eliminated from the diet as a preventive measure to } \\
\text { avoid other reactions }\end{array}$ & Disagree & 131 & 64.2 & 104 & 51.5 & 0.125 \\
\hline
\end{tabular}

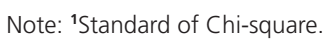


Figure 1A. Non-lgE mediated reactions (0-24 months of age).

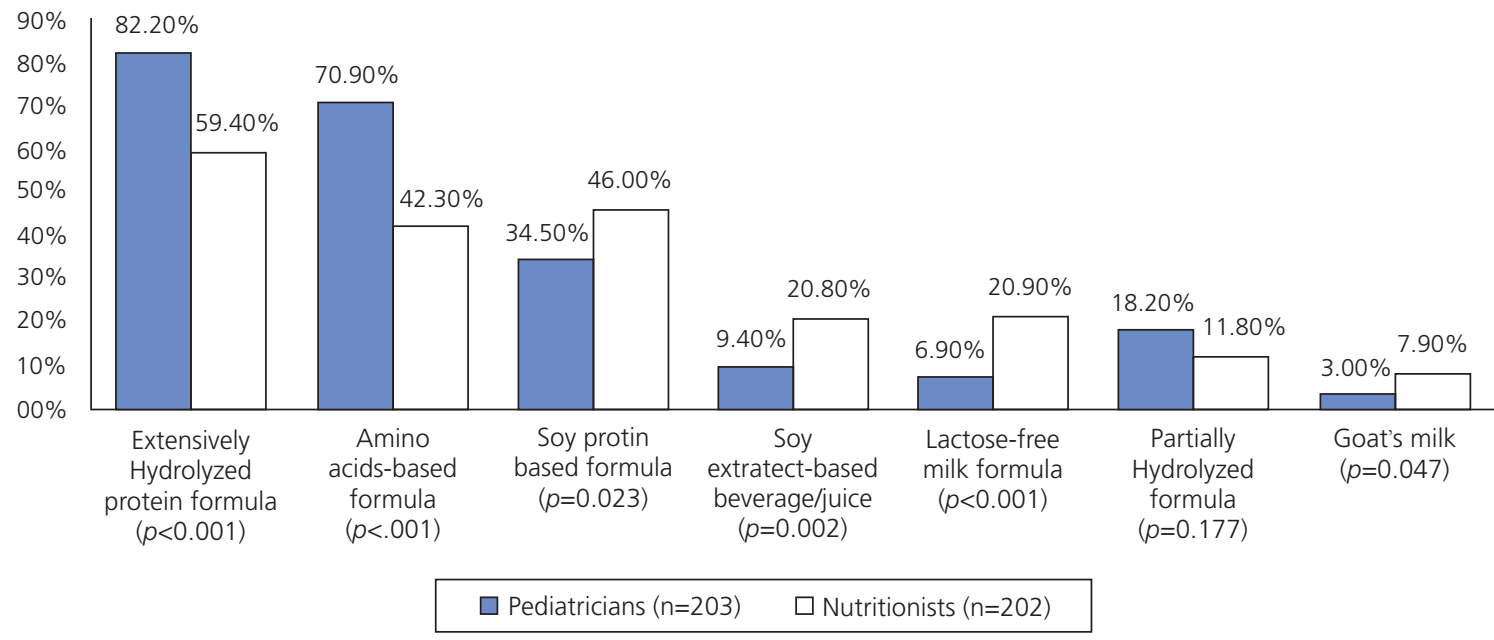

Figure 1B. IgE-mediated reactions (6-24 months of age).

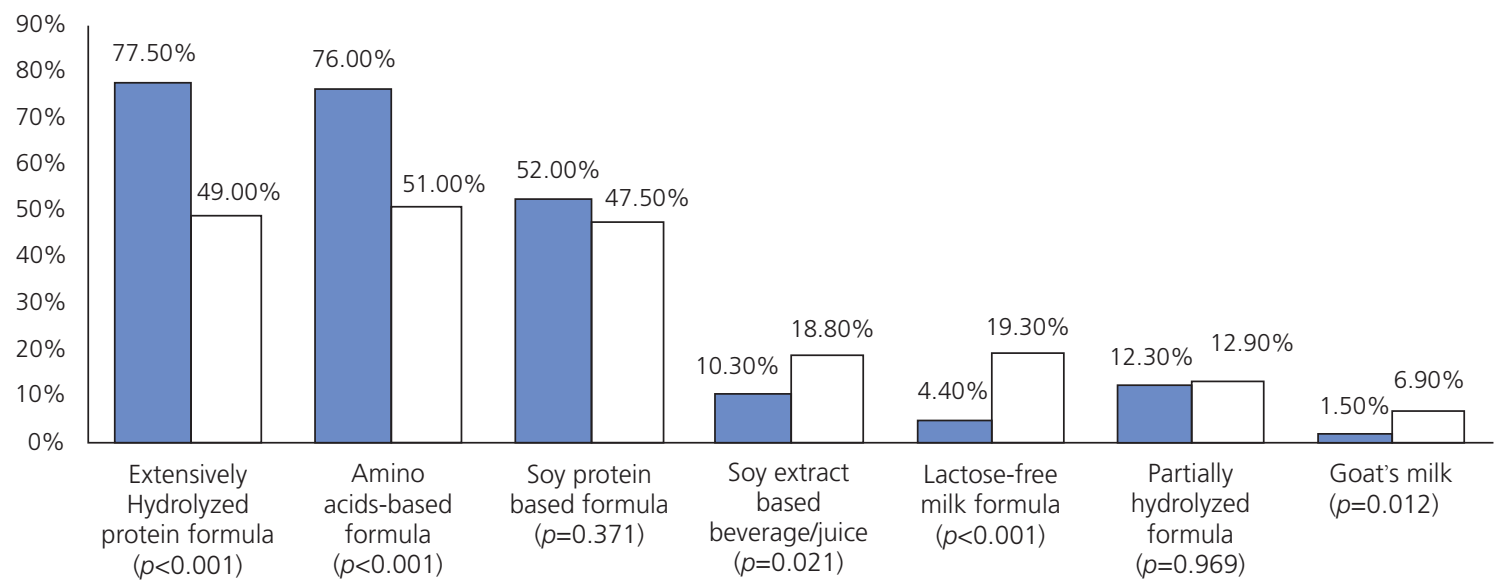

$\square$ Pediatricians $(\mathrm{n}=204) \quad \square$ Nutritionists $(\mathrm{n}=202)$

Figure 1. Options considered suitable by pediatricians and $\mathrm{c}$ for the elimination diet of infants with a suspected or diagnosed allergy to cow's milk protein. São Paulo (SP), Nrazil, 2016.

based formulas, which was considered by pediatricians in $34.5 \%$ of the non-IgE mediated reactions and $52.5 \%$ of the immediate reactions after six months of age and by nutritionists in $46.0 \%$ and $47.5 \%$ of the reactions, respectively.

Between $1.5 \%$ and $21.0 \%$ of the interviewees would use non-acceptable alternatives for the treatment of CMPA, including goat's milk, a beverage or juice based on soy extract, lactosefree milk formula and partially hydrolyzed formula. Some significant differences were found according to the professional category.
Regarding the orientation on reading industrialized product labels, 96.1\% (196/204) of the pediatricians and $82.7 \%$ (167/202) of the dietitians $(p<0.001)$ reported that they provided guidance to parents and/or guardians of children for the identification of all ingredients that might indicate the presence of CMP in industrialized products.

Table 2 presents a series of terms/ ingredients that should/should not be used in the elimination diet of infants with CMPA. The frequency of correct answers generally was 
Table 2. Exclusion recommendation by pediatricians and nutritionists of terms/ingredients observed on labels of industrialized products offered to infants with a suspected or diagnosed allergy to cow's milk protein. São Paulo (SP), Brazil, 2016.

\begin{tabular}{|c|c|c|c|c|c|}
\hline \multirow{2}{*}{ Terms/ingredients } & \multicolumn{2}{|c|}{ Pediatricians $(n=204)$} & \multicolumn{2}{|c|}{ Nutritionists ( $n=202$ ) } & \multirow{2}{*}{$p^{1}$} \\
\hline & $\mathrm{n}$ & $\%$ & $\mathrm{n}$ & $\%$ & \\
\hline \multicolumn{6}{|c|}{ Correct exclusion recommendation } \\
\hline Lactalbumin & 151 & 74.0 & 94 & 46.5 & $<0.001$ \\
\hline Casein & 166 & 81.4 & 127 & 62.9 & $<0.001$ \\
\hline Caseinate & 127 & 62.3 & 101 & 50.0 & 0.169 \\
\hline Milk compound & 163 & 79.9 & 99 & 49.0 & $<0.001$ \\
\hline Whey protein & 145 & 71.1 & 127 & 62.9 & 0.098 \\
\hline Lactic yeast & 120 & 58.8 & 71 & 35.1 & $<0.001$ \\
\hline \multicolumn{6}{|c|}{ Unnecessary exclusion recommendation } \\
\hline Maltodextrin & 18 & 8.8 & 5 & 2.5 & 0.010 \\
\hline Calcium & 3 & 1.5 & 3 & 1.5 & $1.000^{2}$ \\
\hline Hydrogenated vegetable fat & 7 & 3.4 & 8 & 4.0 & 0.984 \\
\hline Calcium stearoyl lactyl lactate & 31 & 15.2 & 26 & 12.9 & 0.595 \\
\hline Lactic acid & 29 & 14.2 & 31 & 15.4 & 0.856 \\
\hline Cocoa butter & 29 & 14.2 & 18 & 8.9 & 0.129 \\
\hline
\end{tabular}

Note: ${ }^{1}$ Chi-square test; ${ }^{2}$ Fischer's exact test.

greater among the pediatricians in relation to the ingredients that should or should not be excluded from the diets of patients with CMPA than among the nutritionists.

Table 3 presents the frequency of correct answers about the calcium recommendation by the pediatricians and nutritionists. Approximately half of the respondents did not respond or indicated that they did not know the answer.

Regarding the first elimination formula that would be recommended for an infant with gastroesophageal reflux disease and a weight deficit, only one alternative was chosen by $366(91.0 \%)$ of the 402 professionals interviewed, of whom 189 were pediatricians and 177 nutritionists. Regarding pediatricians, $58.2 \%(110 / 189)$ would prescribe an extensively hydrolyzed formula, 23.8\% (45/189) would prescribe an amino acid-based formula, 5.8\% (11/189) would prescribe a formula based on soy protein and $12.2 \%$ (23/189) would prescribe other formulas. For the nutritionists, $39.6 \%(70 / 177)$ would prescribe an extensively hydrolyzed formula, $24.3 \%(43 / 177)$ would prescribe an amino acid-based formula, $10.7 \%$
(19/177) would prescribe a formula based on soy protein and $25.4 \%$ (45/177) would prescribe other formulas.

The need for calcium supplementation was questioned in a clinical scenario involving a 15-month-old patient receiving $450 \mathrm{~mL}$ of extensively hydrolyzed formula in addition to complementary feeding. Of the 202 pediatricians, $42.5 \%$ answered that they would supplement calcium. Accordingly, 62 (31.2\%) of the 199 nutritionists would also provide this supplementation. We questioned in which age group calcium supplementation is generally necessary and found that $42.9 \%(85 / 198)$ of the pediatricians and $49.5 \%(100 / 202)$ of the nutritionists required supplementation between 13 and 36 months of age $(p=0.223)$.

\section{DISCUSSION}

Our results showed that the interviewees' knowledge was adequate for most of the contents investigated. However, a non-negligible portion of the professionals interviewed would 
Table 3. Knowledge of pediatricians and nutritionists about the Adequate Intake (Al) and Recommended Dietary Allowance (RDA) of calcium from the Dietary Reference Intakes (DRI) by age group. São Paulo (SP), Brazil, 2016.

\begin{tabular}{|c|c|c|c|c|c|}
\hline \multirow{2}{*}{ Variables } & \multicolumn{2}{|c|}{ Pediatricians $(n=204)$} & \multicolumn{2}{|c|}{ Nutritionists $(n=202)$} & \multirow{2}{*}{$p^{1}$} \\
\hline & $\mathrm{n}$ & $\%$ & $\mathrm{n}$ & $\%$ & \\
\hline \multicolumn{6}{|l|}{ 0-6 months } \\
\hline $200^{*}$ & 31 & 15.2 & 35 & 17.3 & \multirow[t]{6}{*}{0.670} \\
\hline 260 & 4 & 2.0 & 9 & 4.5 & \\
\hline 400 & 31 & 15.2 & 31 & 15.3 & \\
\hline Another dose & 5 & 2.4 & 4 & 2.0 & \\
\hline Do not know & 83 & 40.7 & 60 & 29.7 & \\
\hline Did not answer & 50 & 24.5 & 63 & 31.2 & \\
\hline \multicolumn{6}{|l|}{ 7-12 months } \\
\hline $260^{*}$ & 11 & 5.4 & 30 & 14.9 & \multirow[t]{6}{*}{0.002} \\
\hline 400 & 41 & 20.1 & 32 & 15.8 & \\
\hline 600 & 17 & 8.3 & 24 & 11.9 & \\
\hline Another dose & 4 & 2.0 & 5 & 2.5 & \\
\hline Do not know & 80 & 39.2 & 51 & 25.2 & \\
\hline Did not answer & 51 & 25.0 & 60 & 29.7 & \\
\hline \multicolumn{6}{|l|}{ 13-36 months } \\
\hline 400 & 48 & 23.5 & 24 & 11.9 & \multirow{6}{*}{0.020} \\
\hline $700^{* *}$ & 13 & 6.4 & 28 & 13.9 & \\
\hline 900 & 19 & 9.3 & 32 & 15.8 & \\
\hline Another dose & 6 & 3.0 & 11 & 5.4 & \\
\hline Do not know & 89 & 43.6 & 72 & 35.7 & \\
\hline Did not answer & 29 & 14.2 & 35 & 17.3 & \\
\hline
\end{tabular}

Note: ${ }^{*}$ Values considered correct according to the Al; ${ }^{* *}$ Value considered correct according to the RDA; ${ }^{1}$ Chi-square test.

prescribe inadequate cow's milk substitutes for an infant with suspected or diagnosed CMPA. The results also showed that knowledge and practical guidelines should be improved about the reading of labels of industrialized products and the prescription of calcium supplements. This study meets the demands of pediatricians and nutritionists regarding the clinical practice of treating allergy to cow's milk proteins in infants. Based on this premise, it is important to highlight that these professionals present gaps in the knowledge of the treatment of this clinical entity, which may negatively impact the growth and development of these infants. Thus, our study makes an important diagnosis of the actual situation of the knowledge of these pediatricians and nutritionists about the theme.

Regarding Table 1, most a greater number of nutritionists compared to pediatricians did not believe that a child under an exclusive breastfeeding period could develop CMPA. The same result was found regarding the possibility that milk from other animals could be used as a substitute for cow's milk. Previous study [15] also reported that most dietitians did not agree that infants could develop CMPA when exclusively breastfed. However, food ingested by the mother can be transferred to her child through breast milk $[1,4,11]$. For example, $49.0 \%$ of published cases of eosinophilic colitis occurred during exclusive breastfeeding [23]. 
In total, $44.6 \%$ of nutritionists and $11.8 \%$ of pediatricians agreed that milk from other animals could be used as a substitute for cow's milk for children with CMPA. Previous Research [15] showed that $15.2 \%$ of pediatricians and $13.7 \%$ of nutritionists agreed that milk from other mammals could be used as a suitable substitute for cow's milk. The inadequacy of the use of the milk from other animals is due to the similarity of the proteins from these mammals with the proteins in cow's milk (i.e., there is a high possibility of the occurrence of a crossallergic reaction) $[4,24]$. Conversely, the reaction is not crossed with soy formula. Instead, children with CMPA who develop gastrointestinal tract involvement when soy formula is initiated as a substitute exhibit sensitization $[1,5-7,25]$.

Although soy formulas are not recommended for infants with non-IgEmediated CMPA, the use of this therapeutic option is accepted in infants over six months of age with an IgE-mediated allergy because sensitization to soy formula occurs less often in the immediate reaction $[1,4-7,10,12,25]$. Our results showed that almost all pediatricians and nutritionists wrongly considered a cross-reaction between cow's milk and soybeans a possibility, when in fact there is the possibility of developing sensitization and a reaction after exposure to this type of protein.

Approximately 35.0 to $46.0 \%$ of the interviewees (Figure 1) considered soy protein as an option for children with non-IgE mediated reactions. Conversely, approximately half of the interviewees did not consider soy formula as an option for cow's milk substitution for children with IgE-mediated reactions over six months of age, although this approach is suggested by several guidelines $[1,5,7,10-12,25]$. Virtually all of the guidelines recommend that extensively hydrolyzed formulas be used as the first alternative for children with suspected or diagnosed CMPA, whereas amino acid formulas are recommended for use in severe cases and for patients with persistent symptoms using an extensively hydrolyzed formula $[4,5,7,11,12]$.

In our study, approximately $80 \%$ of pediatricians recognized the extensively hydrolyzed formulas as an option for CMPA treatment, and approximately 70.0 and $76 \%$ of these professionals knew that they could indicate amino acid formulas for cases with non-IgE-mediated and IgE-mediated reactions, respectively. Approximately half of the nutritionists respondents recognized extensively hydrolyzed and amino acid formulas as substitutes for cow's milk. This question sought to explore all possible options for the replacement of cow's milk in infants with CMPA. Cortez et al. [15] found that $66 \%$ of pediatricians and $48 \%$ of nutritionists would indicate at least one product considered inappropriate for the treatment of CMPA.

The choice of substitute formula was evaluated in the question about the first option that would be recommended for a child less than 6 months of age with a weight deficit using infant formula with suspected gastroesophageal reflux secondary to CMPA. For this case, 58.2\% of pediatricians would prescribe an extensively hydrolyzed formula obeying the guidelines $[2,4,5,7,11,12]$. However, $24.0 \%$ of the respondents would prescribe an amino acid formula. In this context, we should note that the guidelines contain no clear definition of serious cases. Thus, the decision to prescribe an amino acid formula was probably motivated by considering the presented case as a serious form of CMPA by least some of these interviewees, since the case presented a weight deficit. Another explanation is that some suggestions from the literature consider the possibility of using amino acid formulas to diagnose CMPA more quickly [26].

During the adoption of the exclusion of CMP diet for children with CMPA, relatives and/or guardians should be guided on reading the labels of industrialized products. Our results were similar to those found in a previous studies $[9,15,27]$ which showed that the majority of 
respondents had difficulty recognizing the terms/ingredients that indicated the presence of cow's milk allergens. In this context, since July 2015, food and beverage labels have been required by the promulgation of the Resolution of the Collegiate Board of Directors - RDC No.26 of the Agência Nacional de Vigilância Sanitária (ANVISA, National Sanitary Surveillance Agency) [28], to contain a description of 18 allergy-causing food ingredients/products, including milk. This regulation is expected to provide conditions for a better understanding of labels by patients and caregivers, thereby solving problems in the identification of allergens demonstrated in Brazil $[9,27]$ and other countries $[29,30]$.

Regarding the recommendation for the daily calcium intake for the different age groups, our findings showed a low level of satisfaction among the professionals interviewed. A previous study [15] showed that only $22 \%$ of pediatricians and $61 \%$ of nutritionists knew the calcium recommendations for all age groups. Some of this knowledge gap is possibly due to the recent changes in the Dietary Reference Intakes (DRI) [31] following the release of new values in 2011 [i.e., 200mg/day (0-6 months), $260 \mathrm{mg} /$ day (7-12 months) and 700mg/day (13-36 months)]. There is no need for calcium supplementation in infants less than one year of age who are receiving more than $500 \mathrm{~mL}$ day of infant formulas for specific dietary needs, since the formulas meet the nutritional needs of the patients [32]. For patients older than one year, the nutritional composition of the diet and the volume of food ingested should be considered, because calcium supplementation may be necessary $[2,32]$. Another important nutrient is vitamin $D$, which aids in the intestinal absorption of calcium and bone metabolism [32].

For the clinical scenario involving the 15 -month-old patient receiving $450 \mathrm{~mL}$ of an extensively hydrolyzed formula in addition to a complementary diet, the percentage of professionals who would not indicate calcium supplementation was higher among the pediatricians than among the nutritionists. The extensively hydrolyzed formulas available in the
Brazilian market contain approximately $50 \mathrm{mg}$ of calcium per $100 \mathrm{~mL}$ of product. A 15 -month-old patient who ingests $450 \mathrm{~mL}$ of the formula daily will receive approximately $225 \mathrm{mg}$ of calcium. Considering that the other foods present in the patient's diet contain 100mg of calcium, $375 \mathrm{mg}$ of calcium should be supplemented.

One of the limitations of our work was that the data collection was performed only at scientific events in the city of São Paulo. In addition to the regional character, professionals who participate in scientific events can be assumed to be more concerned with their scientific knowledge and therefore do not accurately represent the universe of professionals. However, our results are generally similar to the results from other studies [17-25] that evaluated the knowledge and practices of health professionals. These studies [17-25] used procedures for recruiting interviewees that were similar or different to the procedure used herein.

\section{CONCLUSION}

We conclude that gaps still exist in the knowledge and practices of pediatricians and nutritionists about CMPA treatment. Therefore, educational strategies should be proposed and performed to enable these professionals to act in an adequate manner in the establishment of the diagnosis and treatment of CMPA in infants. Thus, it is possible for these professionals to review their therapeutic behaviors for guarantee of the quality of life of the infant, that is, the faster reversal of clinical manifestations and nutritional recovery, avoiding the use of dietary elimination based on inadequate behaviors and that can lead to nutritional deficits, besides rationalizing the use of resources in the treatment of patients with CMPA.

\section{CONTRIBUTORS}

DPB FARIA analyzed data, performed statistical analyses and wrote the paper. APB CORTEZ and PGL 
SPERIDIÃO contributed to writing the manuscript. MB MORAIS reviewed it critically for important intellectual content, analyzed data, and wrote the paper. All authors participated in the conception and design of the study and gave final approval of the submitted version.

\section{REFERE NCES}

1. Koletzko S, Niggemann B, Arato A, Dias JA, Heuschkel R, Husby $S$, et al. Diagnostic approach and management of cow's-milk protein allergy in infants and children: ESPGHAN GI Committee practical guidelines. J Pediatr Gastroenterol Nutr. 2012;55(2):221-9. http://dx.doi.org/10.1097/ MPG.0b013e31825c9482

2. Rona RJ, Keil T, Summers C, Gislason D, Zuidmeer $L$, Sodergren $E$, et al. The prevalence of food allergy: A meta analysis. J Allergy Clin Immunol. 2007;120(3):638-46. http://dx.doi.org/10.1016/j. jaci.2007.05.026

3. Vieira MC, Morais MB, Spolidoro JV, Toporovski MS, Cardoso AL, Araujo GT, et al. A survey on clinical presentation and nutritional status of infants with suspected cow' milk allergy. BMC Pediatr. 2010;10(25):1-7. http://dx.doi.org/10.11 86/1471-2431-10-25

4. Fiocchi A, Brozek J, Schünemann H, Bahna SL, von Berg A, Beyer K, et al. World Allergy Organization (WAO) Diagnosis and Rationale for Action against Cow's Milk Allergy (DRACMA) guidelines. Pediatr Allergy Immunol. 2010;21:1-125. http://dx.doi. org/10.1111/j.1399-3038.2010.01068.x

5. Solé D, Silva LR, Rosário Filho NA, Sarni RO. Sociedade Brasileira de Pediatria e Associação Brasileira de Alergia e Imunopatologia. Consenso Brasileiro sobre alergia alimentar 2007. Rev Bras Alerg Imunopatol. 2008;31(2):65-89.

6. Solé $D$, Silva L, Rodrigues Cocco R, Targa Ferreira C, Oselka Sarni R, Camargo Oliveira L, et al. Sociedade Brasileira de Pediatria e Associação Brasileira de Alergia e Imunologia. Consenso Brasileiro sobre Alergia Alimentar: 2018 - Parte 1: etiopatogenia, clínica e diagnóstico. 2018;2(1):7-38.

7. Solé $D$, Silva $L$, Rodrigues Cocco $R$, Targa Ferreira C, Oselka Sarni R, Camargo Oliveira L, et al. Sociedade Brasileira de Pediatria e Associação Brasileira de Alergia e Imunologia. Consenso Brasileiro sobre Alergia Alimentar: 2018 Parte 2: diagnóstico, tratamento e prevenção. 2018;2(1):39-82.

8. Medeiros LCS, Speridião PGL, Sdepanian VL, Fagundes-Neto $U$, Morais MB. Nutrient intake and nutritional status of children following a diet free from cow's milk and cow's milk by-products. J Pediatr. 2004;80(5):363-70.

9. Weber TK, Speridião PGL, Sdepanian VL, Neto UF, Morais MB, et al. The performance of parents of children receiving cow's milk free diets at identification of commercial food products with and without cow's milk. J Pediatr. 2007;83(5):45964. http://dx.doi.org/10.2223/JPED.1697

10. American Academy of Pediatrics-Committee on Nutrition. Hypoallergenic infant formulas. Pediatrics. 2000;106(2):346-9. http://dx.doi.org/10. 1542/peds. 106.2.346

11. Vandenplas $Y$, Koletzko $S$, Isolauri $E$, Colina $D$, Oranje AP, Brueton $\mathrm{H}$, et al. Guidelines for the diagnosis and management of cow's milk protein allergy in infants. Arch Dis Child. 2007;92(10):902-8. http://dx.doi.org/10.1136/adc.2006.110999

12. Allen KJ, Davidson GP, Day AS, Hill DJ, Kemp AS, Peake JE, et al. Management of cow's milk protein allergy in infants and young children: An expert panel perspective. J Paediatr Child Health. 2009;45(9):481-6. http://dx.doi.org/10.1111/j.14 40-1754.2009.01546.x

13. Muraro A, Werfel T, Hoffmann-Sommergruber K, Roberts G, Beyer K, Bindslev-Jensen C, et al. EAACI food allergy and anaphylaxis guidelines: Diagnosis and management of food allergy. Allergy. 2014;69(8):1008-25. http://dx.doi.org/10. 1111/all.12429

14. Cohen A, Levy B, Leshno M, Katz Y. Food allergy-effect of physician attitude on the diagnosis and reported prevalence. Harefuah. 2005;144(10):685-8.

15. Cortez APB, Medeiros LCDS, Speridião PDG, Mattar RHGM, Neto UF, Morais MB. Pediatricians and nutritionists knowledge about treatment of cow milk allergy in infants. Rev Paul Pediatr. 2007;25(2):106-13.

16. Solé $D$, Jacob CMA, Pastorino AC, Neto AP, Burns DA, Sarinho ESC, et al. Pediatricians' knowledge on food allergy: Pilot study. Rev Paul Pediatr. 2007;25(4):311-6.

17. Gupta RS, Springston EE, Kim JS, Smith B, Pongracic JA, Wang $X$, et al. Food allergy knowledge, attitudes, and beliefs of primary care physicians. Pediatrics. 2010;125(1):126-32. http:// dx.doi.org/10.1542/peds.2009-1116

18. Erkoçoğlu M, Civelek E, Azkur D, Özcan C, Öztürk K, Kaya A, et al. Knowledge and attitudes of primary care physicians regarding food allergy and anaphylaxis in Turkey. Allergol Immunopathol. 2013;41(5):292-7. http://dx.doi.org/10.1016/j.aller. 2012.05.004 
19. Ribeiro CC, Leite Speridiao PG, Morais MB. Knowledge and practice of physicians and nutritionists regarding the prevention of food allergy. Clin Nutr. 2013;32(4):624-9. http://dx.doi. org/10.1016/j.clnu.2012.10.014

20. Maslin K, Meyer R, Reeves L, Mackenzie H, Swain A, Stuart-Smith W, et al. Food allergy competencies of dietitians in the united kingdom, Australia and united states of America. Clin Transl Allergy. 2014;4(37):1-7. http://dx.doi.org/10.1186/2045-70 22-4-37

21. Luyt D, Krishnan MT, Huber P, Clark A. Practice of the treatment of milk allergy in the UK: A national audit. Int Arch Allergy Immonol. 2016;169(1):62-8. http://dx.doi.org/10.1159/000444171

22. Lozinsky AC, Meyer R, Anagnostou K, Dziubak $\mathrm{R}$, Reeve K, Godwin H, et al. Cow's milk protein allergy from diagnosis to management: A very different journey for general practitioners and parents. Children. 2015; 29(3):317-29. http:// dx.doi.org/10.3390/children2030317

23. Lozinsky AC, Morais MB. Eosinophilic colitis in infants. J Pediatr. 2014;90(1):16-21. http://dx.doi. org/10.1016/j.jped.2013.03.024

24. Bellioni-Businco B, Paganell R, Lucenti P, Giampietro $P G$, Perborn $H$, Businco $L$, et al. Allergenicity of goat's milk in children with cow's milk allergy. J Allergy Clin Immunol. 1999;103(6):1191-4. http:// dx.doi.org/10.1016/S0091-6749(99)70198-3

25. Bhatia J, Greer F. American Academy of Pediatrics Committee on Nutrition. Use of soy proteinbased formulae in infant feeding. Pediatrics. 2008;121(5):1062-8. http://dx.doi.org/10.1542/peds. 2008-0564

26. Morais MB, Spolidoro JV, Vieira MC, Cardoso AL, Clark O, Nishikawa A, et al. Amino acid formula as a new strategy for diagnosing cow's milk allergy in infants: Is it cost-effective? J Med Econ. 2016;19(12):1207-14. http://dx.doi.org/10.1080/ 13696998.2016.1211390

27. Binsfield BL, Pastorino AC, Castro APBM, Yonamine $\mathrm{GH}$, Gushken AKF, Jacob CMA. Knowledge of industrialized dairy products labels by parents of patients allergic to cow's milk. Rev Paul Pediatr. 2009;27(3):296-302.

28. Agência Nacional de Vigilância Sanitária. Dispõe sobre os requisitos para rotulagem obrigatória dos principais alimentos que causam alergias alimentares. 2015 [acesso 2016 jun 30]. Disponível em: http://adcon.rn.gov.br/ACERVO/Suvisa/doc/DOC 000000000083199.PDF

29. Noimark L, Gardner J, Warner JO. Parents' attitudes when purchasing products for children with nut allergy: A UK perspective. Pediatr Allergy Immunol. 2009;20(5):500-4. http://dx.doi.org/10.1111/j.139 9-3038.2008.00796.x

30. Zurzolo GA, Koplin JJ, Mathai ML, Tang MK, Allen KJ. Perceptions of precautionary labeling among parents of children with food allergy and anaphylaxis. Med J Aust. 2013;198(11):621-3. http:// dx.doi.org/10.5694/mja12.11669

31. Institute of Medicine. Dietary reference intakes for calcium and vitamin D. Washington (DC): National Academies Press; 2011.

32. Meyer R, Venter C, Fox AT, Shah N. Practical dietary management of protein energy malnutrition in young children with cow's milk protein allergy. Pediatr Allergy Immunol. 2012;23(4):307-14. http:// dx.doi.org/10.1111/j.1399-3038.2012.01265.x

Received: March 22, 2018

Final version: December 17, 2018 Approved: December 20, 2018 